\title{
Peningkatan asupan kalsium menghambat penurunan kepadatan tulang pada perempuan pascamenopause
}

\author{
Sarah Hayati ${ }^{1}$ Elly Herwana ${ }^{2}$
}

\begin{abstract}
ABSTRAK
\section{LATAR BELAKANG}

Osteoporosis banyak terjadi pada perempuan pascamenopause dengan prevalensi $32.3 \%$ pada penduduk Indonesia yang berusia lebih dari 50 tahun. Kalsium merupakan mineral utama pada tulang yang dianggap berperan dalam remodeling tulang. Percepatan remodeling tulang berdampak pada penurunan kepadatan tulang dan meningkatkan risiko fraktur. Penelitian ini bertujuan untuk menilai hubungan antara asupan kalsium dengan kepadatan tulang pada perempuan pascamenopause.
\end{abstract}

\section{METODE}

Penelitian ini merupakan penelitian analitik observasional dengan menggunakan desain potong lintang yang dilakukan pada perempuan pascamenopause. Pengukuran untuk asupan kalsium dari makanan dinilai menggunakan food frequency questionnaire (FFQ). Kepadatan tulang dinilai menggunakan calcaneal quantitative ultrasound (CQU). Analisis data dilakukan secara univariat dan bivariat menggunakan uji Chi-Square.

\section{HASIL}

Sebanyak 92 perempuan pascamenopause berusia 48-60 tahun menjadi subjek penelitian. Hasil analisis asupan kalsium dengan FFQ menunjukkan sebanyak $63(68.5 \%)$ subjek dengan asupan kalsium kategori kurang dan 29 (31.5\%) subjek dengan asupan kalsium cukup (31.5\%). Pemeriksaan kepadatan tulang menggunakan CQU, menunjukkan sebanyak 19 (20.7\%) subjek termasuk kategori kepadatan tulang normal, dan 44 (47.5\%) subjek dengan osteopenia dan 29 (31.5\%) subjek dengan osteoporosis. Analisis statistik didapatkan hubungan yang bermakna antara asupan kalsium dan kepadatan tulang pada perempuan pascamenopause $(\mathrm{p}=0.010)$.

\section{KESIMPULAN}

Peningkatan asupan kalsium menghambat penurunan kepadatan tulang pada perempuan pascamenopause

Kata kunci : asupan kalsium, kepadatan tulang, pascamenopause

\author{
${ }^{1}$ Program Studi Kedokteran, \\ Fakultas Kedokteran, \\ Universitas Trisakti \\ ${ }^{2}$ Departemen Farmakologi dan \\ Farmasi Kedokteran, \\ Fakultas Kedokteran, \\ Universitas Trisakti

\section{Korespondensi:} \\ Elly Herwana \\ Departemen Farmakologi dan \\ Farmasi Kedokteran, \\ Fakultas Kedokteran, \\ Universitas Trisakti \\ Email: elly.herwana@trisakti.ac.id
}

J Biomedika Kesehat 2018;1(2):145151 DOI: 10.18051/JBiomedKes.2018. v1.145-151

pISSN: 2621-539X / eISSN: 2621-5470

Artikel akses terbuka (open access) ini didistribusikan di bawah lisensi Creative Commons Attribution 4.0 International (CC-BY 4.0) 


\section{ABSTRACT}

\section{Increased calcium intake inhibits decreased bone density in postmenopausal women}

\section{BACKGROUND}

Osteoporosis occurs mostly in postmenopausal women with a prevalence of $32.3 \%$ for Indonesians over 50 years of age. Calcium is a major bone mineral that is thought to play a role in bone remodeling. The acceleration of bone remodeling results in a decrease in bone density and increases the risk of bone fracture. This study aims to assess the correlation between calcium intake and bone density in postmenopausal women.

\section{METHODS}

This study was an observational analytic study using a cross-sectional design performed on postmenopausal women. Measurements for calcium intake from food were assessed using a food frequency questionnaire (FFQ). Bone density was assessed using calcaneal quantitative ultrasound (CQU). Data analysis was performed univariately and bivariately using Chi-Square test.

\section{RESULT}

A total of 92 postmenopausal women aged 48-60 years were the subject of the study. The results of the analysis of calcium intake with FFQ showed $63(68.5 \%)$ subjects with low calcium intake and $29(31.5 \%)$ subjects with sufficient calcium intake (31.5\%). Bone density examination using CQU showed 19 (20.7\%) subjects included in the normal bone density category, and 44 (47.5\%) subjects with osteopenia and $29(31.5 \%)$ subjects with osteoporosis. Statistical analysis found a significant relationship between calcium intake and bone density in postmenopausal women $(\mathrm{p}=0.010)$.

\section{CONCLUSION}

Increased calcium intake inhibits decreased bone density in postmenopausal women

Keywords : calcium intake, bone density, postmenopausal

\section{PENDAHULUAN}

Osteoporosis merupakan gangguan metabolik tulang yang ditandai dengan penurunan kepadatan tulang menjadi masalah kesehatan yang perlu diperhatikan karena dapat meningkatkan resiko fraktur tulang. Kelainan osteoporosis yang banyak terjadi pada lanjut usia ini sering kali tidak terdeteksi karena tidak memiliki gejala awal sehingga disebut sebagai silent disease. ${ }^{(1)}$ Penurunan kepadatan tulang menyebabkanosteopenia dan osteoporosis. Osteoporosis menunjukkan tendensi peningkatan prevalensinya di seluruh dunia. Berdasarkan data dari WHO kejadian patah tulang akibat osteoporosis di seluruh dunia mencapai lebih dari 8,9 juta orang setiap tahunnya. ${ }^{(1,2)}$ Osteoporosis terjadi satu diantara 2-3 perempuan pascamenopause, lebih dari $50 \%$ orang diantaranya berusia $75-$ 80 tahun. Jumlah penderita osteoporosis di Indonesia berdasarkan data dari Departemen Kesehatan, meliputi $19.7 \%$ dari seluruh penduduk. ${ }^{(3,4)}$ Data dari riset kesehatan dasar (Riskesdas) menunjukkan bahwa propinsi Jawa Tengah merupakan satu dari lima propinsi di Indonesia yang memiliki risiko tertinggi penderita osteoporosis. ${ }^{(5)}$ Data dari Departemen Kesehatan Republik Indonesia menyatakan bahwa salah satu penyebab tingginya risiko osteoporosis di Indonesia adalah rendahnya konsumsi kalsium rata-rata masyarakat Indonesia yang hanya sebesar 254 $\mathrm{mg} / \mathrm{hari}^{(4)}$

Menopause adalah kondisi fisiologis pada perempuan yang ditandai dengan berhentinya haid secara permanen akibat dari hilangnya aktivitas folikuler ovarium. Perempuan termasuk kategori menopause alamiah bilamana sesudah 12 bulan berturutturut tidak mendapat haid dan tidak ada penyebab patologi atau fisiologi lain yang nyata. $^{(6,7)}$ Rata-rata usia menopause menurut Departemen Kesehatan tahun 2005 yaitu 49 tahun. ${ }^{(8)}$ Defisiensi estrogen pada perempuan pascamenopause ikut berperan sehingga insiden osteoporosis pada perempuan menjadi lebih tinggi. Asupan kalsium dan peran hormon regulator homeostasis mineral tulang dapat mempengaruhi keseimbangan remodeling tulang.

Tulang yang kuat mengandung cukup kalsium, protein dan kolagen. ${ }^{(9)}$ Osteoporosis terjadi akibat proses resorpsi tulang dan pembentukan tulang yang tidak seimbang dalam waktu yang lama. Selsel yang menyebabkan pengikisan tulang 
(osteoklas) bekerja lebih cepat dari pada sel-sel pembentukan tulang (osteoblas) mengakibatkan penurunan kepadatan tulang serta memperburuk mikroarsitektur tulang sehingga tulang menjadi rapuh dan mudah patah. ${ }^{(9,10)}$ Hormon estrogen mengalami penurunan yang signifikan saat memasuki usia 40 tahun. Hormon estrogen sangat berpengaruh dalam keseimbangan remodeling tulang, sebagai anti-resorptif yang bekerja terutama menghambat resorpsi tulang oleh osteoklas. Penurunan hormon estrogen, Vitamin D dan Parathyroid hormone (PTH) dapat pula menyebabkan proses pematangan tulang terhambat dan percepatan proses reabsorbsi tulang. Faktor usia, faktor hormonal dan status menopause seseorang memegang peranan penting dalam penurunan kepadatan tulang, namun terdapat beberapa faktor lain yang juga berpengaruh yaitu gaya hidup, riwayat penyakit, dan asupan zat gizi. Sebelum terjadi osteoporosis, pengurangan masa tulang pada awal menopause akan terjadi perlahan-lahan yang di dahului oleh osteopenia yaitu kondisi dimana tulang memiliki kepadatan mineral tulang yang lebih rendah dari normal. ${ }^{(10-12)}$

Banyak faktor yang berperan terhadap kepadatan tulang. Homeostasis mineral tulang, termasuk pengaturan kadar kalsium dalam darah yang melibatkan asupan kalsium, hormon paratiroid dan vitamin $\mathrm{D}$, memengaruhi remodeling tulang dan berdampak pada kepadatan tulang. Asupan kalsium yang rendah menyebabkan penurunan kadar kalsium dalam darah akan memicu sekresi hormon paratiroid sehingga mengakibatkan peningkatan resorpsi tulang yang menjadi salah satu faktor risiko terjadinya osteoporosis. Kadar kalsium darah dipengaruhi oleh asupan kalsium, vitamin $\mathrm{D}$, dan hormon paratiroid. Asupan kalsium yang berasal dari makanan melibatkan peran hormon vitamin D aktif untuk proses absorbsinya di mukosa usus dan turut menentukan jumlah kalsium yang akan direabsorbsi serta diekskresikan melalui ginjal. Makanan yang memiliki kandungan kalsium tinggi terdapat pada susu beserta produknya seperti keju, kadar yang cukup tinggi juga didapatkan pada kacang dan biji-bijian. ${ }^{(10,12)}$ Seiring dengan bertambahnya usia, tingkat penyerapan kalsium pada tubuh manusia mengalami penurunan sehingga menurunkan kadar kalsium darah, menyebabkan terjadinya hiperparatiroid sekunder dan meningkatkan resorpsi tulang sehingga menyebabkan osteroporosis. Perempuan pascamenopause mengalami penurunan kadar hormon estrogen dan kadar kalsium di dalam tulang. ${ }^{(1)}$ Selain asupan kalsium banyak faktor lain yang dapat mengakibatkan osteoporosis antara lain seperti pola hidup tidak sehat, kurangnya olahraga, defisiensi vitamin D, asupan kafein yang tinggi. Penelitian ini bertujuan untuk menilai hubungan antara asupan kalsium dan kepadatan tulang pada perempuan pascamenopause.

\section{METODE}

\section{Jenis penelitian}

Penelitian ini merupakan studi analitik observasional yang menggunakan desain cross sectional (potong lintang). Penelitian ini dilaksanakan di Kelurahan Sudimara Barat, Ciledug, Tangerang, Banten pada bulan Juli November 2017.

\section{Subjek penelitian}

Subjek penelitian adalah perempuan pascamenopause alamiah yang tinggal disekitar Kelurahan Sudimara Barat, Ciledug, Tangerang, Banten. Perempuan yang mampu berkomunikasi dan bersedia mengisi informed concent. Kriteria eksklusi adalah perempuan yang mengalami menopause akibat pengangkatan rahim, mendapat terapi kortikosteroid, sulih hormon, mengonsumsi suplemen seperti kalsium atau isoflavon. Perhitungan sampel secara finit-infinite menggunakan rumus:

$$
\mathrm{n}=\mathrm{Z} \alpha^{2}(\mathrm{pxq}) / \mathrm{d}^{2}
$$

Prevalensi osteoporosis pada perempuan pascamenopause besarnya $32.2 \%$, pada tingkat kemaknaan $95 \%$ dan keakuratan sebesar 0.05 , maka besar sampel yang diperlukan adalah 336. Jumlah perempuan pascamenopause di wilayah Puskesmas Sudimara adalah 100 orang, serta memperhitungkan drop out 15\%, maka jumlah sampel minimal yang diperlukan 
adalah 89 subjek.

\section{Pengumpulan data}

Subjek penelitian yang telah memenuhi kriteria inklusi dan eksklusi dilakukan wawancara dan diminta mengisi kuesioner. Penilaian terhadap asupan kalsium dilakukan dengan menggunakan food frequency questioner (FFQ). Subjek diminta untuk mencatat jenis makanan dan jumlahnya sesuai dengan kuesioner yang ada dalam tabel FFQ, serta dikonfirmasikan dengan wawancara. Total asupan kalsium dinilai berdasarkan perhitungan penyetaraan kandungan kalsium sesuai asupan makanan dalam kuesioner. Hasil penilaian menunjukkan berapa total asupan kalsium per hari, selanjutnya dikelompokkan sebagai asupan kalsium kurang $(<800 \mathrm{mg} /$ hari $)$ dan asupan kalsium cukup ( $\geq 800 \mathrm{mg} / \mathrm{hari}$ ), sesuai dengan angka kecukupan gizi (AKG) yang ditetapkan Departemen Kesehatan.

Penilaian untuk mengetahui kepadatan tulang dilakukan dengan menggunakan alat Calcaneal Quantitative Ultrasound (CQU). Hasil pengukuran CQU berupa T-Score (Nilai-T) yang dapat digunakan untuk mengkategorikan subjek sebagai kepadatan tulang normal (Nilai-T $\geq-1$ ), osteopenia $(-2.5<$ nilai-T $<-1), \quad$ dan $\quad$ osteoporosis (nilai- $\mathrm{T} \geq-2.5$ ).

\section{Analisis data}

Hasil penelitian akan dianalisis secara univariat dan bivariat. Analisis univariat digunakan untuk mendeskripsikan distribusi karakteristik subjek yaitu usia dan masingmasing variable yang diteliti. Analisis bivariat dilakukan untuk menilai hubungan antara variabel asupan kalsium dan kepadatan tulang. Uji statistik yang digunakan adalah uji Chi-Square dengan menggunakan tingkat kemaknaan 0.05 .

Penelitian ini dilaksanakan setelah memperoleh ethical clearance dari Komisi Etik Penelitian Fakultas Kedokteran Universitas Trisakti dengan Nomor 36/KERFK/VII/2017.

\section{HASIL}

\section{Distribusi karakteristik subjek penelitian}

Penelitian ini melibatkan sejumlah 92 perempuan pascamenopause yang bersedia berpartisipasi dan telah memenuhi kriteria inklusi dan ekslusi serta bersedia menandatangani informed concent. Analisis univariat memperhitungkan frekuensi distribusi karakteristik subjek penelitian.

Tabel 1. Distribusi karakteristik subjek penelitian

\begin{tabular}{lcc}
$\begin{array}{l}\text { Karakteristik } \\
\text { responden }\end{array}$ & $\begin{array}{c}\text { Frekuensi } \\
\mathbf{n = 9 2}\end{array}$ & $\begin{array}{c}\text { Persentase } \\
\mathbf{( \% )}\end{array}$ \\
\hline Usia & 5 & 5.4 \\
$\quad<48$ tahun & 87 & 94.6 \\
$>48$ tahun & & \\
Asupan kalsium & 29 & 31.5 \\
$\quad$ Cukup & 63 & 68.5 \\
$\quad$ Kurang & & \\
Kepadatan tulang & 19 & 20.7 \\
$\quad$ Normal & 44 & 47.8 \\
$\quad$ Osteopenia & 29 & 31.5 \\
$\quad$ Osteoporosis & & \\
\hline
\end{tabular}

Sebanyak 92 perempuan pascamenopause merupakan total subjek penelitian yang telah melengkapi kuesioner. Usia subjek penelitian dipilah atas kurang atau lebih dari 48 tahun, karena rerata usia menopause di Indonesia adalah 48 tahun. Hasil analisis didapatkan sebanyak 5 (5.4\%) subjek penelitian berusia $<48$ tahun dan 87 (94.6\%) subjek penelitian berusia $>48$ tahun (Tabel 1).

Hasil analisis FFQ asupan kalsium diperoleh berdasarkan penyetaraan penilaian terhadap asupan kalsium subjek penelitian per hari. Sebanyak 63 (68.5\%) subjek penelitian mengkonsumsi asupan kalsium dengan kategori kurang dan 29 (31.5\%) subjek penelitian mengonsumsi kalsium dengan kategori cukup. Hasil analisis kepadatan tulang yang diperoleh dari pengukuran CQU menunjukkan bahwa sebanyak 19 (20.7\%) subjek penelitian memiliki kategori kepadatan tulang normal, 44 (47.8\%) subjek penelitian dengan kategori kepadatan tulang rendah/ osteopenia, dan 29 (31.5\%) subjek penelitian dengan kategori kepadatan tulang sangat rendah/osteoporosis (Tabel 1).

Hasil penelitian menunjukkan bahwa subjek penelitian yang mengkonsumsi asupan 
Tabel 2. Hubungan antara asupan kalsium dengan kepadatan tulang

\begin{tabular}{lcccc}
\hline \multirow{2}{*}{ Asupan Kalsium } & \multicolumn{3}{c}{ Kepadatan Tulang } & \multirow{2}{*}{ p* $^{*}$ Osteoporosis (n) } \\
\cline { 2 - 4 } Cukup & Normal (n) & Osteopenia (n) & Osten & 0.01 \\
Kurang & 9 & 17 & 3 & \\
\hline
\end{tabular}

*Uji Chi-square

kalsium selama satu hari dengan kategori kalsium rendah $(<800 \mathrm{mg}$ perhari) memiliki kepadatan tulang dengan kategori normal sebanyak 10 subjek penelitian, kategori osteopenia sebanyak 27 subjek penelitian, dan kategori osteoporosis sebanyak 26 subjek penelitian. Hasil penilaian terhadap asupan kalsium didapatkan bahwa subjek penelitian yang mengkonsumsi asupan kalsium selama satu hari dengan kategori kalsium cukup (>800 mg/hari) memiliki kepadatan tulang dengan kategori normal sebanyak 9 subjek penelitian, kategori osteopenia sebanyak 27 subjek penelitian, dan kategori osteoporosis sebanyak 26 responden. Hasil analisis statistik dengan uji Chi-square menunjukkan terdapat hubungan yang bermakna antara asupan kalsium dengan kepadatan tulang pada perempuan pascamenopause $(\mathrm{p}=0.010)$.

\section{PEMBAHASAN}

Hasil penelitian ini mendapatkan bahwa sebagian besar subjek tergolong dalam asupan kalsium kurang $(<800 \mathrm{mg} /$ hari) yaitu sebesar $68.5 \%$ dan hanya $31.5 \%$ subjek yang menunjukkan asupan kalsium cukup $(\geq 800 \mathrm{mg} /$ hari $)$ untuk memenuhi angka kecukupan gizi yang dianjurkan. Hasil tersebut menunjukan bahwa perempuan pasca menopause sebagian besar tidak menunjukan asupan kalsium yang cukup sesuai yang dianjurkan oleh Angka Kecukupan Gizi Indonesia yaitu $1000 \mathrm{mg}$ per hari.(1) Hasil studi sebelumnya memperlihatkan bahwa sebanyak $33,6 \%$ perempuan pascamenopause menunjukkan asupan kalsium yang rendah $(<800 \mathrm{mg} / \mathrm{hari}) .{ }^{(13)}$ Hasil studi yang serupa didapatkan bahwa rerata asupan kalsium pada populasi perempuan muda di Jepang adalah $309 \mathrm{mg} /$ hari. $^{(14)}$ Beberapa penelitian di Indonesia mendapatkan hubungan bermakna antara perilaku makanan berkalsium dengan kepadatan tulang. ${ }^{(15-19)}$
Proporsi terbesar untuk distribusi kepadatan tulang pada penelitian ini didapatkan $47.8 \%$ subjek termasuk pada kelompok osteopenia. Beberapa hasil studi juga melaporkan bahwa distribusi hasil pengukuran BMD pada perempuan pascamenopase memperlihatkan kelompok osteopenia didapatkan lebih tinggi dibandingkan dengan kepadatan tulang yang normal maupun osteoporosis. ${ }^{(17,19)}$ Banyak faktor lain yang berperan pada kepadatan tulang yaitu lama menopause, aktivitas fisik, indeks masa tubuh, asupan kalsium. ${ }^{(18)}$

Asupan kalsium yang tidak mencukupi kebutuhan sesuai yang di anjurkan (Angka Kecukupan Gizi Indonesia) ${ }^{(1)}$ meningkatkan risiko osteoporosis tiga kali lebih besar dibandingkan dengan asupan kalsium tercukupi. Asupan kalsium yang diperlukan adalah berkisar 1000-1500mg per hari. Absorpsi kalsium paling berperan dalam farmakokinetiknya, sebanyak 300-500mg yang akan diabsorpsi dari asupan kalsium sebanyak $900 \mathrm{mg}$. Jumlah inilah yang perlu ditambahkan dalam asupan kalsium per hari untuk mempertahankan kadar kalsium serum berada dalam keadaan seimbang. ${ }^{(19)}$ Mengkonsumsi makanan sumber kalsium dianjurkan bagi lanjut usia terutama pada perempuan pascamenopause mengingat risiko mengalami osteoporosis lebih besar dengan kondisi menopause dan asupan kalsium yang tidak mencukupi kebutuhan. ${ }^{(16)}$

Penelitian ini memperlihatkan hubungan bermakna antara asupan kalsium dengan kepadatan tulang. Hasil penelitian ini berbeda dengan hasil penelitian sebelumnya yang memperlihatkan bahwa asupan kalsium tidak berhubungan dengan kepadatan mineral tulang. ${ }^{(20)}$ Hal ini disebabkan oleh homeostais kalsium negatif akibat oleh kekurangan asupan makanan, bioavailabilitas dari bahan makanan, penyerapan yang lemah atau 
ekskresinya yang berlebihan mengakibatkan kehilangan kalsium dari tulang.

Beberapa penelitian sebelumnya melaporkan hasil yang sesuai dengan penelitian ini yaitu bahwa asupan kalisum berhubungan dengan kepadatan tulang disertai korelasi positif yang kuat antara jumlah asupan kalsium dan kepadatan tulang. (13-14,21-26) Hasil penelitian lain memperlihatkan bahwa konsumsi susu bersama $250 \mathrm{mg}$ kalsium selama 18 bulan menghambat penurunan BMD yang lebih tinggi daripada konsumsi susu kedelai. Hasil pengukuran BMD didapatkan lebih tinggi pada panggul dan leher femur perempuan pasca menopause di Cina. ${ }^{(22)}$ Asupan kalsium dengan atau tanpa vitamin D yang lebih tinggi memberikan proteksi terhadap osteoporosis yang dinilai berdasarkan hasil pengukuran BMD, tetapi tidak menurunkan risiko terjadinya fraktur pada populasi Kaukasian. ${ }^{(13,23)}$ Hal ini disebabkan karena ada faktor lain yang turut berperan terhadap terjadinya fraktur seperti kelemahan otot, gangguan keseimbangan dan trauma. Asupan kalsium yang lebih tinggi memberikan efek menghambat resorpsi tulang pada perempuan pascamenopause di Korea ${ }^{(24)}$, Jepang $^{(25)}$, dan Sarajevo. ${ }^{(26)}$

Penelitian ini memiliki beberapa keterbatasan penelitian. Alat pengukuran kepadatan tulang karena pada penelitian ini menggunakan Calcaneal Quantitative Ultrasound, yang mungkin memiliki ketelitian lebih rendah dibandingkan pengukuran dengan BMD (Bone Mass Densitometry)/ DXA yang merupakan standar baku. Penelitian ini tidak dilakukan pengukuran kadar kalsium dalam darah sementara asupan kalsium bisa dipengaruhi faktor absorpsi untuk mencapai kalsium darah.

\section{KESIMPULAN}

Peningkatan asupan kalsium menghambat penurunan kepadatan tulang pada perempuan pascamenopause. Perlu dilakukan penelitian lebih lanjut dengan menggunakan Dual X-Ray Absorptiometri (DXA) yang merupakan standar baku untuk pengukuran kepadatan tulang. Selain itu, diperlukan pengukuran kadar kalsium di dalam darah agar penilaian hubungan kalsium dan kepadatan tulang yang lebih baik.

\section{UCAPAN TERIMA KASIH}

Kami mengucapkan terima kasih kepada perempuan pascamenopause yang bersedia berpartisipasi sebagai subjek pada penelitian ini serta pimpinan dan karyawan Puskesmas di Ciledug, Tangerang, Banten yang telah turut memfasilitasi pelaksanaan penelitian ini.

\section{KONFLIK KEPENTINGAN}

Para peneliti tidak memiliki konflik kepentingan pada penelitian ini.

\section{KONTRIBUSI KEPENGARANGAN}

SH berkontribusi pada penyusunan konsep dan rancangan penelitian, pengumpulan data, analisis data dan penyusunan naskah. EH berkontribusi dalam penyusunan konsep dan perbaikan naskah. Semua penulis telah membaca naskah dan memberikan persetujuannya.

\section{DAFTAR REFERENSI}

1. Peraturan Menteri Kesehatan Republik Indonesia tentang Angka Kecukupan Gizi yang di anjurkan bagi Bangsa Indonesia. Jakarta: Kemenkes RI; 2013. 5 p. Report No.:75.

2. Cosman F, deBeur SJ, Leboff MS, et al. Clinician's guide to prevention and treatment of osteoporosis. Osteoporosis Int. 2014. 25(10): 2359-81.

3. World Health Organization. WHO scientific group on the assessment of osteoporosis at primary health care level: Summary Meeting Report, Brussels, Belgium, 5-7 May 2004. Geneva: World Health Organization; 2007 [cited 2017 Jun]. Available from: www.who.int/chp/topics/Osteoporosis.pdf

4. Pusat Data dan Informasi Kementrian Kesehatan RI. Infodatin: Data \& Kondisi Penyakit Osteoporosis di Indonesia [Internet]. Jakarta: Pusat Data dan Informasi Kementrian Kesehatan RI; 2015 [cited 2017 May]. Available from: http:// www.depkes.go.id/resources/download/pusdatin/ infodatin/infodatin-osteoporosis.pdf

5. Badan Penelitian dan Pengembangan Kesehatan Kementrian Kesehatan RI. Riset Kesehatan Dasar 2013. Jakarta: Kemenkes RI; 2013. Available from: http://www.depkes.go.id/resources/download/ general/Hasil\%20Riskesdas\%202013.pdf

6. Nelson HD. Menopause. The Lancet. 2008;371:760-70.

7. Tria AEP. Hubungan asupan kalsium dan faktor risiko lainnya dengan kejadian osteoporosis pada kelompok dewasa awal di wilayah CiputatTangerang Selatan. Jurnal Kedokteran dan Kesehatan. 2011; 7(2):7.

8. Departemen Kesehatan Republik Indonesia. 
Terjadi pergeseran umur menopause. Jakarta: Depkes RI; 2006

9. Calvez J, Poupin N, Chesneau C et al. Protein intake, calcium ballace and health consequences. European Jurnal of Clinical Nutrition. 2012;66:281-95.

10. Tandra H. Osteoporosis : Mengenal, Mengatasi, dan Mencegah Tulang Keropos. Jakarta : PT Gramedia Pustaka Utama. 2009. p.6.

11. Santoro N, Randolph JF Jr. Reproductive hormones and the menopause transition. Obstet Gynecol Clin North Am. 2011; 38(3):455-66.

12. Linder MC. Biokimia Nutrisi dan Metabolisme. Jakarta: Penerbit Universitas Indonesia; 2006. p. 215 .

13. Jackson RD, LaCroix AZ, Gass $M$ et al. Calcium plus vitamin $\mathrm{D}$ supplementation and risk of fracture. N Engl Jmed. 2006;254:669-83.

14. Ito $\mathrm{S}$, Ishida $\mathrm{H}$, Uenishi $\mathrm{K}$ et al. The relationship between habitual dietary phosphorus and calcium intake, and bone mineral density in young Japanese women: a cross-sectional study. Asia Pac J Clin Nutr. 2011;20:411-7.

15. Triatmaja NT, Khomsan A, Dewi M. Asupan Kalsium, Status Gizi, Tekanan Darah dan Hubungannya dengan keluhan Sendi Lansia di Panti Werdha Bandung. Jurnal Gizi dan Pangan. 2013;8(1):25-32.

16. Soke YE, Judha M, Amestiasih T. Hubungan Pengetahuan Lansia Tentang Osteoporosis dengan Perilaku Mengkonsumsi Makanan Berkalsium di Panti Wredha X Yogyakarta. Jurnal Keperawatan Respati. 2016;3(1):66-71.

17. Fitri Y, Masrul, Vitria. Kejadian Osteoporosis Pada Wanita Premnopause Di Wilayah Kerja Puskesmas Santun Usila tahun 2010 Berdasarkan Tingkat. Pengetahuan Dan Tindakan Pencegahan. Jurnal Kesehatan Masyarakat Andalas. 2010;5(2):6-9.

18. Koesyani AS. Hubungan Asupan Kalsium, Aktivitas Fisik, Paritas, Indeks Massa Tubuh, dan Kepadatan Tulang pada Wanita Pascamenopause [Tesis]. [Semarang]: Universitas Diponegoro; 2007. $112 \mathrm{p}$.

19. Fitria R. Hubungan Indeks Massa Tubuh, Paritas dan Lama Menopause dengan Densitas Mineral Tulang pada Wanita Pasca Menopause. Jurnal Maternity and Neonatal. 2016;2(2):68-73.

20. Rachmawati FR. Pengetahuan Gizi Sikap Perilaku Makan dan Asupan Kalsium pada Siswi SMA [Skripsi]. [Semarang]: Universitas Diponegoro; 2012. 23 p

21. Fikawati R. Syafiq . Gambaran Konsumsi Kalsium Remaja. Dalam: Fikawati, R. \& Syafiq (eds). Gizi dan Kesehatan Masyarakat. Jakarta: Fakultas Kesehatan Masyarkat Universitas Indonesia; 2007. 253-6 p.

22. Gui JC, Brasie JR, Liu XD et al. Bone mineral density in postmenopausal Chinese women treated with calcium fortification in soymilk and cow's milk. Osteoporos Int. 2012;23:1563-70. DOI 10.1007/s00198-12-1895-z

23. Nieves JW, Barrett-Connor E, Siris ES et al. Calcium and vitamin D intake influence bone mass, but not short-term fracture risk, in Caucasian postmenopausal women from the National Osteoporosis Risk Assessment (NORA) study. Osteoporos Int. 2008;19:673-9. DOI 10.1007/ s00198-007-0501-2

24. Kim MK, Chon SJ, Noe EB et al. Associations of dietary calcium intake with metabolic syndrome and bone density among the Korean population: KNHANES 2008-2011. Osteoporos Int. 2017;28:299-308. DOI 10.1007/s00198-0163717-1.

25. Nakamura K, Saito T, YoshiharaAetal. Low calcium intake is associated with increased bone resorption in postmenopausal Japanese women: Yokogoshi study. Public Health Nutr. 2009;12:2366-70. Doi: $10.1017 / \mathrm{S} 1368980009005084$.

26. Kapetanovic A dan Avdic D. Dietary calcium intake and osteoporosis in postmenopausal women living in Sarajevo area. J Health Sci. 2012:2:11821 . 